William \& Mary Law School

William \& Mary Law School Scholarship Repository

Fall 2020

\title{
The Changing Role of the American Prosecutor
}

Jeffrey Bellin

William \& Mary Law School, jbellin@wm.edu

Follow this and additional works at: https://scholarship.law.wm.edu/facpubs

Part of the Criminal Procedure Commons, and the Law Enforcement and Corrections Commons

\section{Repository Citation}

Bellin, Jeffrey, "The Changing Role of the American Prosecutor" (2020). Faculty Publications. 2026. https://scholarship.law.wm.edu/facpubs/2026

Copyright c 2020 by the authors. This article is brought to you by the William \& Mary Law School Scholarship Repository.

https://scholarship.law.wm.edu/facpubs 


\title{
The Changing Role of the American Prosecutor
}

\author{
Jeffrey Bellin*
}

\section{PRESCRIPT}

The following is a November 2019 presentation to the Louisiana District Attorneys Association, Fall Meeting of Elected District Attorneys ("DA"). The invited presentation was part of an agenda that included remarks from the Governor of Louisiana and the Chief Justice of the Louisiana Supreme Court. The opinions expressed are solely those of the author.

These remarks have been edited for clarity and brevity. Some discussion specific to Louisiana, as well as the speaker introduction, and exchanges with the audience during and after the talk are excluded. A short postscript follows the remarks.

Thanks to [Baton Rouge District Attorney] Hillar Moore for the introduction, and to the District Attorney's Association for the invitation. As Hillar suggests, you may not agree with all that I am going to say, but I hope you will find it helpful. I think if you want to understand any complex topic it's important to talk to people you don't already agree with.

I've been researching and writing about prosecutors for a couple of years now, partly because I didn't agree with some of the writing that was out there. Very smart people were missing some of the complexity of the role of the prosecutor. The other thing that pushed me in this direction is that it has become an interesting time to be a prosecutor. The perception of the prosecutor position is changing dramatically.

Before I get to the changing role of the prosecutor, I want to provide some context. I am going to start with how we got to this point on the way to talking about, (1) what should the role of prosecutors be, and (2) what lessons does the progressive prosecution movement offer for prosecutors who don't necessarily want to adopt the term "progressive."

* Professor, William \& Mary Law School. Professor Bellin was a prosecutor in Washington, D.C., prior to becoming a law professor. Thanks to David Sklansky for a helpful discussion in the days leading up to the talk, and Diana Bibb for research assistance. 


\section{MASS INCARCERATION}

Let's start with an abbreviated summary of mass incarceration. The familiar story begins with a crime spike. ${ }^{1}$ Crime went up in the 1960 s, 70 s, and 80 s, and at the same time crime was going up, there was a public perception that the criminal justice system was not responding. Media reports suggested that people were committing crimes without consequences. This meant not only stories about crime, but also stories about a revolving door of criminal justice. The public and public officials responded with harsh new laws and "tough on crime" attitudes.

Prior to all that, this country had an incarceration rate comparable to European countries. ${ }^{2}$ With the perception of sharply increasing crime and subsequent political reaction, we get a spike in the incarceration rate that makes this country unique. What is mass incarceration, then? One answer is that it is much higher incarceration rates versus historical averages. The other way to frame it is by comparison to other countries. Either way, we're at the top; we have the highest incarceration rate in the world. ${ }^{3}$ Historically and comparatively.

Of particular interest to this audience, there's an argument out there that prosecutors are the driving force for mass incarceration. That's what drew me into writing about these topics. That seemed really interesting, but the data didn't support it. $^{4}$

Judges, police, legislators were not taken by surprise by prosecutors suddenly pushing for everyone to go to prison. All of these actors were on the same page. This isn't a prosecutor phenomenon. It's a societal phenomenon. That's not an exoneration of prosecutors. Prosecutors likely became more severe, just like legislators, judges, police, and everybody else in the system. Mass incarceration arose through a consensus of these criminal justice actors.

\section{A. "No Crime Left Behind"}

Zoom in from the bigger picture and you can get an understanding of how this works. You've heard of "No Child Left Behind." America had a parallel movement of "No Crime Left Behind." Think of all the crimes that we started treating more severely. And notice that there are always rhetorical arguments you can make for treating each crime severely - that's how we get here. There are a few crimes where

1 For an account of the rise of mass incarceration, see NAT'L RESEARCH COUNCIL, THE Growth of INCARCERATION IN THE UNITED STATES: EXPLORING CAUSES AND CONSEQUENCES 1-9 (Jeremy Travis, Bruce Western \& Steve Redburn eds., 2014), https://www.nap.edu/catalog/18613/thegrowth-of-incarceration-in-the-united-states-exploring-causes.

2 Id. at 34-37.

3 Id.

4 See Jeffrey Bellin, Reassessing Prosecutorial Power Through the Lens of Mass Incarceration, 116 MiCH. L. Rev. 835 (2018). 
the change is easy to see. Start with drunk driving. There's a Supreme Court case from 1984 where the Court downplays the law enforcement need to pursue a drunk driver into his home because the underlying offense was "a noncriminal, civil forfeiture offense for which no imprisonment is possible." That seems dated now, but it reflects the enormous change in how our society sees drunk driving. Same with domestic violence. With domestic violence cases, the argument for a severe response often focuses on the escalation of domestic violence. What looks like a misdemeanor assault case today can become a more serious injury case, or even a murder down the road. Obviously, "violent crimes" like murder and rape continue to appear at the center of arguments for penal severity, so you don't need me to construct a narrative for that. For drugs, you see a general public sentiment that, of all the crimes, drug crimes aren't as serious. But if you talk about individual drugs, people will say, "Well heroin, that's really a serious drug. We have the opioid crisis. We need to treat that severely." "Cocaine, crack, that's a serious drug." Go back and look at historical discussions of crack cocaine and the damage it was doing to vulnerable communities. ${ }^{6}$ That allowed politicians to construct a compelling narrative that crack cocaine had to be treated severely. Even marijuana. If you talk to police about marijuana you'll sometimes hear, "marijuana's not so bad in-and-of-itself, but the people that are selling it or the gangs that are running the marijuana, those are the really violent gangs." Suddenly you've got an argument for responding severely to marijuana because of the ancillary problems that come with marijuana trafficking. Sexual assault is treated more severely than it used to be. Child pornography. Unlawful firearm possession. Prostitution becomes increasingly framed as sex trafficking. Even theft. You'd say, "Come on. There's no argument for treating theft severely." Then you talk to police about lowering the felony threshold for theft, and you start to hear about "shoplifting gangs" that are going to take advantage of a lower threshold.

The point is not that any one of these crimes are responsible for mass incarceration, or that they should or shouldn't be treated severely. The point is that when you look at crimes in isolation, you see how easy it is to make a case for severity to an increasingly receptive public. It's these individual processes that, together and over time, generate a larger phenomenon.

We end up with a mindset that spreads to legislators, police, judges, and prosecutors that everything that the criminal justice system potentially reaches is very serious. Violations become misdemeanors. Misdemeanors become felonies. Sentences go up across the board; we add mandatory minimum sentences. "Truth in sentencing" replaces indeterminate, rehabilitative sentencing and parole. Pardons dry up. Throughout the system, everyone is increasing severity. It's not just prosecutors, and it's not just judges or police or legislatures. It is everything working

5 Welsh v. Wisconsin, 466 U.S. 740, 754 (1984).

6 See James Forman, Jr., Locking Up Our Own: Crime and Punishment in Black America (2017). 
together. Maybe even with some good intentions for steps along the way, but there's an ugly big picture consequence.

The big picture is skyrocketing incarceration. ${ }^{7}$ You can make a list of every country's incarceration rate and include the rates of each of the states, and almost all the states have higher rates than the first non-U.S. country. ${ }^{8}$

\section{B. Mass Incarceration, Norway, and Larry Bird}

That's the big picture, but what does this mindset that severity is the answer look like at the ground level? The example that sticks out in my mind is a case from 2005 , where a defendant enters a thirty-year plea deal in Oklahoma. ${ }^{9}$ The defendant is a big fan of Larry Bird, the basketball player. Larry Bird's jersey number is 33 . But the defendant only got thirty years. At the hearing, he tells the judge that he wants his sentence to match Larry Bird's jersey. The judge basically says, "Okay! I'll give you thirty-three years if that's what you want." 10 That's crazy, the idea that we would just give out extra punishment like it's nothing. Society doesn't need the extra three years. We'd hope the judge would say, "I don't have an interest in adding three years to your sentence just because you want a certain number." But, another part of it - and this is something I want to emphasize-is that without actually asking the prosecutor, the judge said, "I know the DA is happy about it."11 That's an actual quote from the hearing. Prosecutors should reject this idea that they are mindless champions of severity.

Severity is contextual. There's a guy in Norway who killed seventy-seven people in 2011 , an atrocious crime. ${ }^{12}$ Norway sentenced him to twenty-one years. ${ }^{13}$ Why twenty-one years? That's the max in Norway. ${ }^{14}$ You can imagine at the sentencing hearing, the judge saying, "This is an atrocious crime. I'm giving you the max." Obviously, that's not the max in the United States-not even close.

7 Peter Wagner \& Wendy Sawyer, States of Incarceration: The Global Context 2018, PRISON POL'Y INITIATIVE (June 2018), https://www.prisonpolicy.org/global/2018.html.

8 Id.

9 Felon Gets Longer Sentence to Match Bird Jersey, ESPN (Oct. 20, 2005), https://www.espn.com/nba/news/story?id=2198534.

$10 I d$ (The judge said about the request," $[w]$ e accommodated his request and he was just as happy as he could be.").

11 Id.

12 Mark Lewis \& Sarah Lyall, Norway Mass Killer Gets the Maximum: 21 Years, N.Y. TimEs (Aug. 24, 2012), https://www.nytimes.com/2012/08/25/world/europe/anders-behring-breivik-murdertrial.html.
13 Id.
$14 \quad I d$. 
Compare that to the notorious case from Louisiana in 1996 where someone stole a jacket and gets life without the possibility of parole. ${ }^{15}$ It's a totally different world. In the United States, the max is through the roof for things that nobody would describe as atrocious crimes. Ratcheting up severity for some crimes pushes severity up for all crimes. If you're giving out huge sentences for drug crimes or habitual offenders, that pushes the ceiling higher for murderers or rapists. For an American judge to express outrage, the judge has to compete with life sentences for stealing a jacket. A judge that just sentenced a guy to life for theft is going to have a hard time imposing a lower sentence for an armed robbery, murder, or rape. That pressure affects legislators, judges, police, and prosecutors.

\section{Changing Perceptions}

That's the mass incarceration story in a nutshell. But things are starting to change. It took a while, but the public and the media are beginning to notice this astronomical incarceration rate. Perhaps most famously, there is the book, The New Jim Crow, ${ }^{16}$ a book you should read if you haven't already. It's probably the most successful crossover law professor book in history. I remember seeing it in an airport bookstore. I thought, "How could a law professor's book be selling in an airport?" It's because it hit at just the right time. The public hadn't thought through the effects of all this severity. Suddenly, there's a book saying that the criminal justice system is a continuation of Jim Crow. ${ }^{17}$ That gets peoples' attention.

There is also more attention to injustice in individual cases. There's the Innocence Movement highlighting wrongful convictions. ${ }^{18}$ Shows like Making $a$ Murderer $^{19}$ and podcasts like Serial ${ }^{20}$ highlight cases where convicted defendants might be innocent. There's a non-fiction book that becomes a Netflix series called Orange is the New Black about a woman's experience in prison. ${ }^{21}$ One of the themes is that even when people are guilty of serious crimes, prison may not be the answer.

These media portrayals, reaching huge audiences, put a new kind of pressure on the criminal justice system. The pressure that led to penal severity and ultimately mass incarceration, remember, came from two things: (1) a perception of suddenly App. 1998).

is State v. Jackson, 706 So. 2d 494, 495 (La. Ct. App. 1997), vacated, 718 So. 2d 1001 (La. Ct.

16 See Michelle Alexander, The New Jim Crow: Mass Incarceration in the Age of COLORBLINDNESS (2010).

17 See id.

18 See The InNOCENCE ProjeCt, https://www.innocenceproject.org/ (last visited Jan. 12, 2020).

19 Making a Murderer (Netflix 2015).

20 Serial: Season One, Serial Productions (2014), https://serialpodcast.org/season-one.

21 Orange Is the New Black (Netflix 2013). 
spiking crime; and (2) a sense that the criminal justice system is not taking it seriously. Now we have crime going down and a sense that the criminal justice system is over-punishing. There's suddenly a lot of room for broad critiques of the criminal justice system. There's a focus on racism in the system with Black Lives Matter. Gender critiques start becoming more powerful with the "Me Too" movement. All of these things are putting pressure on the criminal justice system, police, prosecutors, legislatures, and judges.

The pressure is not all in the same direction; some pressure is pushing for lenience and some isn't. One common mainstream framing you see is a focus on proportionality. The system's priorities seem to be in the wrong place. With all these resources, effort, and severity dedicated to criminal justice, how are so many serious crimes unsolved? People hear about mass incarceration and low clearance rates. We've got murder clearance rates in some cities that are around $15 \% .{ }^{22}$ You can literally get away with murder. This suggests a need to reshuffle our priorities.

One obvious priority shift is away from the drug war. It couldn't be more obvious that the drug war is not stopping people from using or selling drugs. We just get new evolutions. If you read about the opioid epidemic, people are structuring heroin trafficking in a way that makes it almost impossible for the criminal justice system to respond sensibly. ${ }^{23}$ The criminal justice system is never going to solve this problem, and it is not costless. Trying to deal with drugs through the criminal justice system does not solve the problem; rather, it floods the courts with cases.

The evidence of changing perceptions is all around. You may be familiar with the famous "Willie Horton" political ad used against Michael Dukakis. ${ }^{24}$ Now the political sphere is filled with other messages. Donald Trump trumpets the First Step Act, which shortens federal prison sentences. ${ }^{25} \mathrm{He}$ 's echoing the message that there

22 See Patrik Jonsson, Solving the Unsolved: How Cities are Turning Up Heat on Cold Cases,

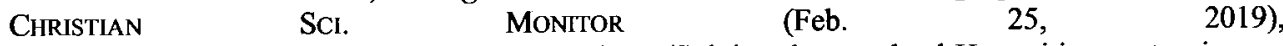
https://www.csmonitor.com/USA/Justice/2019/0225/Solving-the-unsolved-How-cities-are-turningup-heat-on-cold-cases (citing Detroit's clearance rate was 15\% in 2016); Aamer Madhani, Unsolved Murders: Chicago, Other Big Cities Struggle; Murder Rate a 'National Disaster,' USA ToDAY (Aug. 10, 2018, 3:19 PM), https://www.usatoday.com/story/news/2018/08/10/u-s-homicide-clearance-ratecrisis $/ 951681002 /$. (citing the low clearance rate of Detroit, Chicago, Indianapolis, and other large cities).

23 See Sam Quinones, Dreamland: The True Tale of America's Opiate Epidemic (2015).

24 See Peter Baker, Bush Made Willie Horton an Issue in 1988, and the Racial Scars Are Still Fresh, N.Y. TIMES (Dec. 3, 2018), https://www.nytimes.com/2018/12/03/us/politics/bush-williehorton.html.

25 See Rachel Frazin, 2,200 Federal Inmates to Be Released Under Criminal Justice Reform Law, THE HILl (July 13, 2019, 4:35 PM), https://thehill.com/blogs/blog-briefing-room/news/452947more-than-1 100-have-been-released-under-the-first-step-act. Trump ran a Super Bowl advertisement emphasizing this point as part of his reelection campaign. Annie Karni \& Maggie Haberman, Trump and Kushner Saw Super Bowl Ad as Way of Making Inroads With Black Voters, N.Y. Times (Feb. 4, 2020), https://www.nytimes.com/2020/02/04/us/politics/trump-super-bowl-ad.html. 
are people in prison who don't need to be there. Kamala Harris would traditionally have been a very strong contender for the Democratic presidential nomination, but she's playing defense because she wasn't enough of a "progressive prosecutor" when she was the District Attorney in San Francisco and then California's Attorney General. ${ }^{26}$

\section{Changing Prosecutor Politics}

There are two interesting pieces to the Kamala Harris story for elected DAs. One is that being too severe - too tough on crime - can be a political problem. Two, critics can tag chief prosecutors with everything that happened in their office. Harris is getting criticized for cases handled by the California Attorney General's Office. ${ }^{27}$ That's the second biggest department of justice in the country. Thousands of cases. Hundreds of attorneys. Harris is taking political hits because some of those attorneys in some of those cases made questionable decisions about disclosing evidence on her watch. ${ }^{28}$ This will connect with a point about discovery practices I am going to make later on.

Add to this bipartisan criminal justice reforms that are bubbling up like the First Step $\mathrm{Act}^{29}$ and surprising figures like the Koch brothers ${ }^{30}$ tying reforms to conservative ideas: government overreach and wasting taxpayer money. For a long time, people critiqued reformers by saying there's not a proven track record for incarceration alternatives. Now, people are asking "What's the evidence that prison works?" What do we get in return for spending all this money on punishment (conservatives), and inflicting all this suffering (liberals)? It's a hard question to answer.

26 See, e.g., Meagan Flynn, 'You Owe Them an Apology': Gabbard's Attack Highlights Harris's Complex Death Penalty Record, Wash. Post (Aug. 1, 2019, 9:22 AM), https:/www.washingtonpost.com/nation/2019/08/01/you-owe-them-an-apology-gabbards-attackhighlights-harriss-complex-death-penalty-record/.

27 See Lara Bazelon, Opinion, Kamala Harris Was Not a 'Progressive Prosecutor,' N.Y. TIMES (Jan. 17, 2019), https:/www.nytimes.com/2019/01/17/opinion/kamala-harris-criminal-justice.html.

28 Id.

29 See First Step Act, FED. BUREAU OF PRISONS, https://www.bop.gov/inmates/fsa/ (last visited Sept. 30, 2020).

30 See Philip Elliott, The Koch Brothers Are Pushing for Criminal Justice Changes, TIME (Jan. 29, 2018, 5:09 PM), https://time.com/5123969/koch-brothers-criminal-justice-reform/. 


\section{THE ROLE OF THE PROSECUTOR: LESSONS FROM "PrOGRESSIVE PROSECUTION"}

Now we get to the main event, the role of the prosecutor. Why are prosecutors suddenly the focus of attention? Why does it resonate to blame the system's failings on prosecutors? How are prosecutors able to run on a promise to reform the system?

Part of what's going on is that we've never figured out in this country what the prosecutor is supposed to be doing. If you ask prosecutors what their role is, they'll say the prosecutor's job is to "do justice." Sounds great. It's better than saying the prosecutor's job is to get convictions. But "do justice" is an aspiration, not a directive. When you get to the grey areas, it is not clear what justice means, and a lot of criminal law is grey. One person could look at a case and say this should be dismissed; another person could look at it and say this case should be prosecuted to the fullest extent of the law. Both people could say, "This is justice to me." It's a kind of freedom, but it's also a double-edged sword. That makes it easy to look at failures in the criminal justice system and blame the prosecutor. It's the prosecutor's fault because the prosecutor is supposed to do justice, and this is unjust.

That's where progressive prosecutors come in. They're saying, "The system is unjust. Elect me as a prosecutor and I'll do justice." What is the progressive prosecutor's idea of justice? It's usually less (unnecessary) severity, decriminalizing poverty, and eliminating racial bias. It's hard to argue with any of that. But, obviously, the details matter.

There are examples across the country of prosecutors picking up the mantle of reform. In Dallas, there's a progressive prosecutor who says he's not going to prosecute some minor crimes. ${ }^{31}$ Seattle's DA won't prosecute certain drug charges. ${ }^{32}$ Kim Foxx in Chicago criticized Illinois' unusually low $(\$ 300)$ felony theft threshold. When the legislature didn't change it, she said, she wouldn't charge it as a felony unless it's $\$ 1000 .{ }^{33}$ Most importantly, these prosecutors are politically successful.

This all complicates one of the main themes we've heard from DAs over the years: "Don't blame me. I just enforce the law. If you have a problem with the law, talk to the legislature." Now you have progressive prosecutors saying, "Well, if you don't like the law, I'll take care of it." Your constituents who see that happening in Chicago can say, "Why can't that happen here in Baton Rouge or New Orleans?"

31 See Catherine Marfin, Texas Prosecutors Want to Keep Low-Level Criminals Out of Overcrowded Jails. Top Republicans and Police Aren't Happy., TEx. TRIB. (May 21, 2019, 12:00 AM), https://www.texastribune.org/2019/05/21/dallas-district-attorney-john-cruezot-not-prosecutingminor-crimes/.

32 See Nicholas Kristof, Opinion, Seattle Has Figured Out How to End the War on Drugs, N.Y. Times (Aug. 23, 2019), https://www.nytimes.com/2019/08/23/opinion/sunday/opioid-crisis-drugseattle.html.

33 See Steve Schmadeke, Top Cook County Prosecutor Raising Bar for Charging Shoplifters with Felony, CHI. TRIB. (Dec. 15, 2016, 6:00 AM), https://www.chicagotribune.com/news/breaking/ctkim-foxx-retail-theft-1215-20161214-story.html. 
The truth is-and you know this--that it's not the case that the prosecutor just prosecutes everything that police bring to them. There's more to the job than enforcing the law.

There's a study out of New Orleans when Harry Connick Sr. was the DA. ${ }^{34}$ At the same time that the life-sentence-for-stealing-a-jacket case is going on, two academics were studying the New Orleans DAs office. They reported that the office declined to prosecute over $50 \%$ of the cases police brought to them. ${ }^{35}$ It's a hidden truth about prosecutors since the dawn of time. There are cases that come through the door that you're not going to prosecute for lots of reasons. The last thing you're going to hold yourself to is, "I've got to prosecute it because it's a violation of the law."

This brings me to the synergies between progressive prosecution and good, competent prosecution. A lot of the things that progressive prosecutors are talking about are things that all prosecutors should be doing.

\section{A. Prosecutors Should Follow the Rules}

One thing that should be obvious is that prosecutors must follow the rules. ${ }^{36}$ One of the ways you see progressive prosecutors getting traction is by emphasizing that they're going to follow the rules that all prosecutors are supposed to follow. For example, Brady v. Maryland says you have to disclose exculpatory information. ${ }^{37}$ That includes evidence that impeaches government witnesses. ${ }^{38}$ That means if you have a police officer testifying in your case, you have to disclose impeachment information that calls into question the credibility of the officer. That includes stuff that might be in their police employment file, as well as cases where a judge has found that the officer lied.

Philadelphia's progressive DA, Larry Krasner, recently announced that he's going to develop a list of police with impeachment information. ${ }^{39}$ That became a big news story. Everybody's celebrating. The real question is how was there not already a list? In the United States Attorney's Office for the District of Columbia in the

34 See Ronald Wright \& Marc Miller, The Screening/Bargaining Tradeoff, 55 STAN. L. REV. $29,67-82$ (2002).

35 Id. at 74 ("[T]he NODA office rejects for prosecution in state felony court $52 \%$ of all cases and $63 \%$ of all charges.").

36 For a longer discussion of the importance of following rules to the prosecutor's role, see Jeffrey Bellin, Theories of Prosecution, 108 CAL. L. REV. 1203 (2020).

37 Brady v. Maryland, 373 U.S. 83, 87 (1963).

38 United States v. Bagley, 473 U.S. 667, 676 (1985) ("Impeachment evidence, . . . as well as exculpatory evidence, falls within the Brady rule.").

39 See Avery Anapol, Philadelphia DA Moves to Create Database of 'Problem' Cops, THE HILL (June 5, 2018, 3:34 PM), https://thehill.com/homenews/state-watch/390827-philadelphia-da-movesto-create-database-of-problem-cops. 
2000s, we had something called the "Lewis list." ${ }^{\text {40 }}$ It's the same thing. Why did we have it? Not necessarily because my office was progressive. We had a list because if we didn't have a list, we would be violating Brady whenever one of these officers testified and someone in our office or at the police department knew there was impeachment material out there and we didn't disclose it. The office had hundreds of prosecutors. ${ }^{41}$ We needed a list. That's just basic constitutional prosecution. So, one place all prosecutors should be agreeing with the progressive prosecution movement is on the basic point that prosecutors have to follow the rules.

One of the themes I always stress is that just because it's hard to get caught violating some of these rules doesn't let prosecutors off the hook. Prosecutors swear an oath to uphold the Constitution. They have to follow those rules even if there is little likelihood they will be caught if they don't.

\section{Office-Wide Policies}

There are two pieces: office-wide policies and training. Let's start with policies. I don't know what kind of discovery practices you have, but if I were running an office, I would have an open file discovery system where defense attorneys could come and look at our files. Obviously, if there's an address in there that's going to get a witness killed, you can redact it and let the defense attorney know that you are holding that back. But if you don't have an open file system, you're playing, what I call, "Brady Roulette." You are taking huge chances, particularly as judges' and voters' perceptions of the criminal justice system change. These gambles will eventually come back to haunt you. Maybe not in every case, but in one case. If you're running an office, you need to think comprehensively, "How do we identify exculpatory information that is somewhere in my office or the police files? How do we get that out to the defense?" If you're not thinking about that, I can guarantee that exculpatory evidence will fall through the cracks. That violates the law. That's a problem not just for progressive prosecutors, but for all prosecutors.

\section{Taking Training Seriously}

Elected DAs also need to think hard about their training programs. Training can't be about how to argue, after the fact, that there should be no consequences. For

40 See Cunningham v. United States, 974 A.2d 240, 242 n.3 (D.C. 2009) ("The 'Lewis list' is a computerized list, maintained by the Office of the United States Attorney for the District of Columbia, preserving information that might be used to impeach police officers if they testify."); Steve Reilly \& Mark Nichols, Hundreds of Police Officers Have Been Labeled Liars. Some Still Help Send People to Prison., USA TODAY (Oct. 17, 2019, 3:26 PM), https://www.usatoday.com/indepth/news/investigations/2019/10/14/brady-lists-police-officers-dishonest-corrupt-still-testifyinvestigation-database $/ 2233386001 /$.

41 About Us, U.S. ATT'Y's OFF. D.C., https://www.justice.gov/usao-dc/about-us (last updated June 4, 2019). 
example, prosecutors too often end up arguing at the margins about the evidence they didn't disclose, "It's not material so I didn't have to disclose it." Maybe you're right about that, but why take the chance? If it wasn't material, what was the problem with disclosure? If you are arguing about it after the conviction, of course, it's too late. The judge may disagree with you and you have to try the case again. The victim has to testify again. That makes no sense. Prosecutors should default to disclosing everything.

If the jury seeing all the evidence means you can't win your case, then that's the system working. Sometimes juries acquit-that's the point of a trial. In retrospect, one of the best things about being a prosecutor in DC was that we lost cases. It wasn't the end of the world. And since we weren't terrified of losing, it was easier to follow rules that might lead to an acquittal or hung jury. We knew through experience that the system was bigger than us.

Another illustration is the constitutional rule that you cannot strike a juror based on race. ${ }^{42}$ Obviously, you need to train attorneys on these rules, but it's also important to frame the prosecutor's role as compatible, not in conflict with, the rules. It can't be framed - and you see this too often-as here's how to survive the Batson challenge. That's missing the point. If I ran an office, my message would be, "We don't violate Batson in my office, because we don't violate the law." Of course, there are other reasons not to use race in jury selection, but that's the easiest. You're the elected DA. You represent the people and you swear an oath to uphold the Constitution. The Constitution dictates that you cannot strike jurors based on race. The message to your attorneys has to be, "We don't do this." Who cares if a sneaky attorney can "get away" with race-based strikes? That's not how prosecutors should think. My message to my attorneys would be, "I don't want to hear about you getting challenged for Batson. Make your strikes so far on the right side of the line that this isn't going to be an issue for my office. If you can't do that, don't use strikes."

\section{B. What Prosecutors Shouldn't Be Doing}

One of the clearest ways to think about the role of the prosecutor is to think about all of the things that prosecutors should not be doing. Prosecutors should not be a rubber stamp for the police. Prosecutors should not be reflexively rejecting claims of innocence. They should not be seeking loopholes in discovery or jury selection rules. Prosecutors need to embrace the rules because those rules make the system work. The prosecutor doesn't have the final say in who is guilty. The prosecutor is part of a system. The system gives defense attorneys the role of advocating for their clients, and to do this they need the exculpatory information in your files. All of the evidence has to come out for the jury to make an informed decision. Prosecutors should embrace all of this by welcoming the scrutiny that comes with disclosing evidence and letting juries hear it. Prosecutors should

42 See Batson v. Kentucky, 476 U.S. 79, 97 (1986). 
embrace the idea that if the twelve fairly selected, fully informed jurors aren't convinced, the defendant walks. That's the system.

Prosecutors shouldn't be anywhere close to the lines we hear about them crossing. I see cases that come up through the appellate system that are filled with landmines. If I'm reading a case, and the first issue is that the prosecutor struck all the African American jurors, my antenna is up-"What's going on?" How unsure are the prosecutors in their evidence that they're pushing right up to the line of permissible jury selection? Next, the case relies on a jailhouse informant who claims he heard the defendant confess. Really? Then there's some questionable forensics evidence that no scientist would credit outside of court. Next, the prosecutor succeeded in getting the judge to exclude defense evidence about a possible thirdparty perpetrator. Maybe you can win a case like that. Even if you win that case, though, you're looking at years of post-conviction litigation. And even worse, the person might not even be guilty. ${ }^{43}$

This gets back to where we started: What's the role of the prosecutor? Is it the role of the prosecutor to drag whatever case the police give them, warts and all, to the finish line? Of course not. Part of the prosecutor's job is to turn to the police or the victim and say, respectfully, "We just don't have the evidence." It can be framed a lot of ways:

- "The jury won't return a guilty verdict."

- "I can't risk putting an innocent person in prison."

- "I don't want to be doing habeas and appeals on this case for the next twenty years."

- "This is racial injustice and how we got mass incarceration."

Whatever it is, you can ask the police to go back and investigate some more. "When we get a solid case, we'll prosecute it. Until then, I've got lots of other cases to handle."

\section{Prosecutors and Severity}

Another thing about the prosecutor's role I want to highlight is that there is nothing about the role of the prosecutor that means the prosecutor should embrace severity. There's no part of "do justice" that means, "I want more convictions. I want more punishment." To the extent that perception is out there, we need to ask why

43 See Mark Schlinkmann, Lincoln County Voters Sweep Out of Office 2 Key Figures in Faria Murder Case, St. Louis PosT-Dispatch (Aug. 9, 2018), https://www.stltoday.com/news/local/crimeand-courts/lincoln-county-voters-sweep-out-of-office-key-figures-in/article_41 fbd1b3-a621-59f5a $412-40 \mathrm{~d} 544337 \mathrm{e} 55 . \mathrm{html}$ (reporting on prosecutor voted out of office after obtaining conviction of likely innocent person). 
that is. Where is that coming from? Look at the Larry Bird example. Why would the DA be happy that the judge added three years to the defendant's thirty-year sentence?

One of the things you hear is, "The victims want severity." Even if that is true (and it varies by victim), the prosecutor does not represent the victim. Prosecutors know this. It's evident in the cases where the prosecutor doesn't follow the victim's wishes, for example where the victim asks to "drop the charges," but the prosecutor still goes forward. The other thing that complicates the idea that the prosecutor represents the victim is that the victim in one case can become the defendant in the next. Think of a series of retaliatory shootings. Obviously, prosecutors should care about and support crime victims. That doesn't automatically translate into seeking a particular conviction or sentence or implementing the wishes of a particular person. In this country, victims don't prosecute cases. Instead, prosecutors make independent judgements.

Prosecutors also don't represent the police. The prosecutor sits between the police and the court system. Maybe the police are getting everything right in your jurisdiction. In my experience, some police officers do things by the book, and some don't. Since some police officers bend the rules or make mistakes, prosecutors need to be independent. That's why one of the most important roles of the prosecutor is screening out rotten cases.

The next thing you hear often is that severity is necessary for public safety. In some cases, that's true. But it is an empirical question. What does the data show? There are a bunch of components. Maybe you're saying, "I'm going to prosecute this severely to deter other people from committing these crimes." If so, you need to understand studies of deterrent effects. This evidence suggests that prosecutors will struggle to achieve appreciable deterrence because of low clearance rates. Clearance rates for homicides average around $60 \%$ across the country. ${ }^{44}$ Some places are much lower. ${ }^{45}$ The numbers plummet for typical crimes.

The research suggests that people are deterred from committing a crime if they think they are likely to get caught. ${ }^{46}$ The model we have is lots of people committing statutory crimes, a handful getting caught, and then (maybe) a severe sentence. That is not a recipe for deterrence. ${ }^{47}$ Think of crimes like drug dealing or theft. I haven't

442018 Crime in the United States, Table 26: Percent of Offenses Cleared by Arrest or Exceptional Means, FBI: UCR (2018), https://ucr.fbi.gov/crime-in-the-u.s/2018/crime-in-the-u.s.2018/tables/table-26.

45 See Jonsson, supra note 22; Madhani, supra note 22.

46 See Daniel S. Nagin, Deterrence in the Twenty-First Century, 42 CrImE \& JuST. 199, 202 (2013) (reviewing empirical literature and concluding that "certainty, not severity, is the more effective deterrent.").

47 Id. at $252-53$ ("There is little evidence that increasing already long prison sentences has a material deterrence effect. Evidence on the deterrent effect of the certainty of punishment is more consistent, but the source of the effect is less clear."). 
seen anyone attempt to calculate the clearance rate for shoplifting, drug dealing, or drug use, but it is probably less than $1 \%$. That's a real problem for deterrence. The people you are trying to send a message to know that better than you do. This means severity in the handful of cases is not going to be effective in terms of deterrencethat's what the research shows.

The other argument is that you can achieve public safety by incapacitating certain offenders. The challenge here is identifying the small number of individuals who might truly warrant incapacitation with lengthy prison terms. How good are prosecutors at identifying those individuals? I'm skeptical. But it's an empirical question and it needs to be thought about rigorously. It can't be, "One of these thirty people is going to be a problem going forward, so all of them have to serve a lengthy prison term." There has to be more rigor to it than that.

What about retribution: punishment to achieve "justice?" Prosecutors need to be really careful there; they are not experts in morality, philosophy, or religion, the kind of things that would tell us how much punishment someone "deserves."

\section{Prosecutor Fixing the System}

Last, I want to discuss things the prosecutors could do to make the system work better. There are a lot of problems that are not the prosecutor's fault. Other people are mucking things up and the question becomes, what can prosecutors do to help? That's where the progressive prosecutor idea gets interesting. Part of what's new about the progressive prosecutor is that it's not the progressive prosecutor fixing prosecution practices. It's the progressive prosecutor fixing judges, fixing the legislature, fixing the police, and essentially counteracting the decisions of other criminal justice actors.

\section{Lowering the Volume}

One thing prosecutor can do to make the system work better across the board is to shrink the volume of cases. This is so important. It's easy to defend the American criminal justice system in the abstract. It's a good system, but we've dumped piles of cases on it. You know this from your own courts. No system can handle this volume of cases. Volume is the enemy of justice. If you want to have a just system, whatever your theory, then high case volume is your number one problem. As a District Attorney, you can control the volume to a degree. You should be looking for ways to do that whenever you can.

I thought of this recently as I was reading Preet Bharara's new book, Doing Justice ${ }^{48} \mathrm{He}$ was the United States Attorney for the Southern District of New York. I've only gotten through some of the book, but the motto he keeps going back to is,

48 Preet Bharara, Donng Justice: A Prosecutor's Thoughts on Crime, Punishment, And THE RULE OF LAW (2019). 
"Do the right thing, in the right way, for the right reasons." ${ }^{\text {"49 }}$ In my mind, reflecting on my time as a state-level prosecutor, I'm thinking, "That's easy for you to say." The Southern District of New York has a handful of carefully selected cases, just a few per prosecutor, and all these resources. We all want to do the right thing the right way for the right reason. My experience as a line prosecutor in D.C. Superior Court pointed me to a different motto. My motto would have been, "Survive and Advance." I I was thinking, "Get through today so I can show up to work tomorrow." Why? Because it was chaos. I had all these cases-multiple cases up for trial every day. Things popping up on the calendar that I didn't know anything about. I could be sent to cover someone else's trial at the last minute. It's hard to do the right thing in the right way in those circumstances because you're just trying to survive the moment. You don't have the time to take a step back and think, "What's the right solution to this case?" when the judge is saying, "Are your witnesses here? Are you ready to pick a jury?"

For line prosecutors to have any chance at doing justice, it's critically important to decrease the volume of cases. How do you decrease the volume? One way is you can decline to prosecute certain cases. Which cases should you decline to prosecute? Obviously, the less important ones. And you can think about "less important" in a lot of different ways, but one way is high-volume crimes that aren't going to result in significant formal punishment. These cases are people flowing through the system, without any clear benefit to anyone, such as shoplifting, driving on a suspended license, and drug possession. That's what progressive prosecutors are saying. But what's interesting is even these progressive prosecutors are making these statements in a way that's going to appeal to most people. They're saying, "Our priority is violent crime. We're not going to mess around with these possession of marijuana cases." I think if you talked to the average Louisianan, they'd say, "That makes sense." This isn't crazy; it's not even progressive. Larry Krasner, one of the most prominent progressive prosecutors, says he is going to get rid of these marijuana cases and that " [w] could use those resources to solve homicides." "51 I think most people would say, "Yeah, that sounds good." Rachael Rollins, the new DA in Boston, is saying something similar. ${ }^{52}$

49 Id. at xiv.

so This is a commonly used slogan for how to succeed in the NCAA "March Madness" basketball tournament.

51 Brian X. McCrone, Marijuana Criminal Cases Dropped En Masse by Philadelphia District $\begin{array}{llllll}\text { Attorney, NBC } & \text { (Mar. } & 19, & 2018, & 6: 13 & \text { PM), }\end{array}$ https:/www.nbcphiladelphia.com/news/local/marijuana-criminal-cases-dropped-en-masse-byphiladelphia-district-attorney-larry-krasner/205152/.

52 See Andrew Martinez, DA Rachael Rollins Targets 1,300-plus Unsolved Murders, Bos. HERALD (Sept. 26, 2019, 7:35 PM), https:/www.bostonherald.com/2019/09/26/da-rachael-rollinstargets-1300-plus-unsolved-murders/; Andrea Estes \& Shelley Murphy, Stopping injustice or putting the public at risk? Suffolk DA Rachael Rollins's tactics spur pushback, Bos. GLoBE (July 6, 2019, 5:57 
You can frame the same idea in a variety of ways. Every prosecutor focuses on some cases at the expense of others. It's just a question of degree. The thing about the small cases, as someone who handled lots of small cases, is that they are not so small. There is tons of stuff you have to do in all these cases. Every case has lots of moving pieces. You have to get drug analysis from a chemist on the littlest drug case, recordings of 911 calls, and police officer notes. You need all of the police radio traffic and body camera videos because you have to check if there is exculpatory information in there. A prosecutor can pursue these cases. Maybe it's worth the resources, but if you have other things to do with those hours and hours of prosecutor time, you can reasonably say, "In a world of finite resources, I have to prioritize certain cases and that means I don't go forward on others." That's why we elect our DAs - so they can make hard decisions like that.

There are many benefits to reducing volume. I just talked about the prosecutor, but everybody in the system touches these cases. When I worked as a local prosecutor, some judges routinely put defendants on drug testing, and then responded to every positive test. Defendants would be relieved when they got probation, but if they were using drugs they were in for a shock. They'd test positive once for marijuana and the judge would put them into drug treatment, with the sentence hanging over their head. This small decision triggers a stream of officialsthe probation officer, the court clerk-all working to cure this person of their marijuana addiction. That was not a good use of resources. DC needed that money and those people and hours for other things. Prosecutors who care about the system need to think about those effects: "Are these cases worth it?" Because so many people are touched. Not just the defendant. A probation officer who has 200 cases is going to be a terrible probation officer, but give that same probation officer fifty cases, and now you might really turn some people around. It shouldn't only be the prosecutor's responsibility, but maybe the prosecutor needs to step in in light of how things have gone.

\section{Eliminating Bad Incentives}

Another thing I want to talk about is the need to remove bad incentives from prosecutors' offices and the system itself. It's hard enough to get the answers right without distortions. Now imagine there's something that pushes prosecutors to consider improper things, like money. Say, for example, the prosecutors' office is funded by court costs from convicted defendants, or prosecutors are worried about the county's civil liability for a bad arrest. This extends to everyone in the system. How problematic is it if public defenders are funded through fines, as is the case in Louisiana? Now the public defender has an incentive for their clients to be convicted! Judges may have the same incentive. If court fines and costs are funding

PM), https://www.bostonglobe.com/metro/2019/07/06/stopping-injustice-putting-public-risk-suffolkrachael-rollins-tactics-spur-pushback/lFC6Rp4tVHiVhOf2t97bFI/story.html. 
the criminal justice system, everybody has an additional interest in convictions, but not dismissals. ${ }^{53}$

There is a Supreme Court case, Connally v. Georgia, that makes this point. ${ }^{54}$ In Georgia, in the 1970s they had a system where a magistrate got paid per warrant: $\$ 5$ for every warrant issued, and no money for warrant applications that were denied.$^{55}$ The Supreme Court said that violated the Constitution. The magistrate has to be neutral. ${ }^{56}$ The opinion includes an excerpt from a deposition of the magistrate in the case. With regard to the compensation system, they asked him, "[D]oes [the compensation] enter your mind when you're sitting there contemplating whether or not to issue a search warrant?" The magistrate agreed that it had, saying, "It's only human nature to me." ${ }^{57}$ The sentiment is jarring, but it speaks to a truth that we don't want to admit. Money is a powerful incentive.

To the extent that DAs are going to lobby against things, it makes sense to lobby against incentives that distort prosecutors' ability to make the right choices. DAs should also be thinking about helping other criminal justice actors to make the right choices. Part of the role of the prosecutor is to try to make the system sane and make the system work fairly and legitimately. If, for example, public defenders depend on convictions and fines to fund their offices, they have an incentive to convict their clients. That's not sane. Prosecutors should care about that.

\section{Separation of Powers: Prosecutors v. Legislatures}

One objection you hear to the kinds of things I am talking about is that they violate the separation of powers and the system's checks and balances. Aren't prosecutors usurping the legislature's role when they don't prosecute cases that they think are unimportant? There is this sense that prosecutors are stepping out of their proper role unless they are doing what the legislature, police, or judges want. But actually, it's the opposite. The system is set up so that there are checks and balances on putting people in prison. That's how checks and balances work in the criminal justice system. The police arrest, the prosecutor charges, the judge approves a plea deal or a jury determines guilt, the judge sentences, and parole or a pardon are available on the back end. These are checks and balances on the government putting people in prison. Think of the police officer who gives a warning instead of a speeding ticket. We don't see people saying, "The officer violated the separation of powers!" Each role here- the prosecutor, the police officer, the parole officer, the

53 See Micah West, Louisiana Should Eliminate Money Bail, NOLA.COM (July 22, 2019, 3:13 PM), https://www.nola.com/opinions/article_cf3ca3d0-7adf-5625-9154-268ce50a262c.html.
54 Connally v. Georgia, 429 U.S. 245 (1977).
55 Id. at 245.
56 Id. at 251 .
57 Id. at 246 n. 3 . 
pardon board, the judge - is checking the State's power to punish people ${ }^{58}$ You can say, "I don't want the prosecutor to do these things because the legislature should decide," but it's not a problem of checks and balances or separation of power, it's just a policy dispute. You can't prosecute everything. If you accept that, then you have to prioritize some cases over others. I'm not saying to avoid prosecuting a drug case because you do not believe drugs should be criminalized. You don't have to go that far. Just say, "We have other things we are prioritizing and these minor drug cases are at the bottom of the list," or, "There's not going to be any real punishment at the backend anyway, so why spend a ton of resources and review all the body camera footage for this?"

There are also some serious cases that prosecutors reach out for that they should be declining. These are grey area legal cases that involve serious harms. A caregiver leaves a baby in the car, and the baby dies. Someone texts someone awful things, and the person commits suicide. A friend or dealer gives drugs to someone who overdoses and dies. Prosecutors can and do bring these cases. ${ }^{59}$ They are really hard to win - lots of motions and hearings and repeated appeals. That's a major use of resources. Why is the prosecutor doing that? What is the purpose of bringing that case? The answer can't be, "It's the law." The legislature wasn't thinking about drug delivery homicides when they passed the murder statute in 1780 . The other argument is that prosecution makes people safer. Where is the data? These prosecutions are so rare. It's complete speculation that people are going to change their behavior based on ad hoc prosecutions. At the end of the day, then, prosecutors pursuing these cases are devoting limited resources based on speculation.

Sentencing enhancements are another place to think about discretion. It's interesting the way legislatures structure many of these enhancements, like habitual offender laws. Often the statute doesn't just tell the judge to look at the record at sentencing and say, "Okay, this is your third offense. You get life." Usually, the prosecutor has to file something to trigger the enhancement. The Louisiana habitual offender statute says the prosecutor "may" file an enhancement in certain circumstances..$^{60}$ That's the legislature signaling to prosecutors that you don't have to do this. My inclination would be to not add severity unless there's a good reason beyond, "the law lets me do this," or "this person may continue to commit this crime,

58 For more on this conception of the prosecutor as one of the checks and balances on the State's power, see Jeffrey Bellin, Defending Progressive Prosecution, 39 YALE L. \& PoL'Y REV. (forthcoming Fall 2020).

59 See, e.g., Lateshia Beachum, Michelle Carter, Who Went to Jail for Encouraging Her Boyfriend to Kill Himself, is Denied Parole, WASH. Post (Sept. 20, 2019, 12:14 PM), https://www.washingtonpost.com/crime-law/2019/09/20/michelle-carter-who-went-jail-encouragingher-boyfriend-kill-himself-is-denied-parole/; Rosa Goldensohn, They Shared Drugs. Someone Died. Does That Make Them Killers?, N.Y. TIMES (May 25, 2018), https://www.nytimes.com/2018/05/25/us/drug-overdose-prosecution-crime.html.

60 LA. STAT. ANN. \& 15:529.1(D)(1)(a) (2019) (“. . . the district attorney of the parish in which subsequent conviction was had may file an information accusing the person of a previous conviction."). 
so I'll put them in prison for twenty years." Again, we need to ask, what is the purpose of the prosecutor?

\section{Prosecutors v. Judges}

Those are examples of the prosecutor as a check on legislative severity. Prosecutors can also operate as a check on other criminal justice actors. Here's an example. My first calendar judge issued warrants for people who signed notice to appear but missed a court date. This was a misdemeanor docket and we had lots of cases where we would dismiss the case if, after a certain period of time, the defendant hadn't committed another offense. We called it the STET docket. The same thing happened with diversion cases. You completed community service, didn't get arrested again, and, on a set date, we dismissed the case. Those cases often had a court date set in case the conditions were not fulfilled. Sometimes the defendant didn't show up. Why? Maybe they forgot or didn't realize they had to come back to court. The clerk would call the case, the defendant wouldn't be there. The judge would issue a bench warrant. Defense attorneys didn't even object. Finally, I spoke up, "Your honor, the United States is not asking for a warrant to issue. We were going to dismiss the case. There's no need to bring someone back to court for that." The judge looked at me and said, "I don't care what you are asking for. This person signed a notice to show up in my courtroom today and they didn't honor a promise to this court, so I'm issuing a bench warrant.". It's her courtroom, I get it. But to my mind that was a waste of resources: police resources, court resources, the defendant's resources, and essentially everybody's resources. For what?

After that, I started writing dismissal notices for those cases. Before the judge took the bench, I'd give the clerk the one-sentence notice that said we "hereby" dismiss the case. The clerk put it in the case file and she wouldn't call the case. Since the case never got called, the judge never knew the defendant wasn't there, and she didn't issue a bench warrant. I don't know if people think that was right or wrong, but it's an example of what prosecutors can do to check the power of other criminal justice actors.

Bail presents a related issue. You could say, "If you have a problem with bail, legislatures created bail rules and judges set bail." But prosecutors are in the mix too. They request bail, and bail plays a major role in some cases. Here's an example. Say you've got someone sitting in jail and you're going to offer them a plea deal to time served. That means they can get out of jail today, if they plead guilty. Or they can sit in jail for another couple weeks or months to get a trial. That's crazy if you think about it: you are offering a better outcome for pleading guilty than the defendant will get if they go to trial and are acquitted. And it's often not the prosecutor's fault that the person is being held or that the system is so congested that the trial has to be delayed. But it's absolutely nuts. It puts a ton of pressure on people to plead guilty even when they're not guilty. It actually becomes rational to falsely plead guilty. That calls into question the integrity of the system. What can the 
prosecutor do? One thing is to minimize the number of people held on bail. If they are already held, try to get them out first-put everything on the table. "First, I'll ask the judge to release you today." Second and unconnected to that, "Here's the plea deal. You can take it and then you'll be done, or we'll have the trial whenever it's set in the next six months." This lets the defendant choose between the plea deal and a trial. What is the role of the prosecutor? I think part of the prosecutor's role is to try to fix problems in the system, even if those problems aren't the prosecutor's fault.

Let me stop there so I can leave time for your reactions and questions. Thank you again for hearing me out.

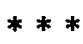

\section{POSTSCRIPT}

As might be expected, questions from the audience pushed back on some of the points set out above, but the response was predominantly practical, as opposed to ideological. For example, one prosecutor challenged a compilation I highlighted of Louisiana districts that, according to USA Today, did not have Brady lists for police officers. ${ }^{61}$ The prosecutor did not object to my argument that DAs office should have lists. Instead, she insisted that, contrary to USA Today's reporting, her office had a list - a response I passed along to USA Today. ${ }^{62}$

More generally, the Louisiana prosecutors' willingness to invite a law professor to speak to so prominent a gathering suggests interest in reform. In conversations before and after the talk, these prosecutors seemed to be open to thinking about how to decrease the footprint of the criminal justice system-although they do not speak in the same terms as progressive prosecutors. The reforms they would support are also likely more modest, though potentially more impactful given the severity of legislatures and judges in many "non-progressive" jurisdictions. In fact, Louisiana had just recently enacted a series of reforms with support from the State's prosecutors. Apart from the upcoming LSU-Alabama football game, the primary topic of conversation around the meeting was that Oklahoma had just released a large number of prisoners. This placed Louisiana in danger of once-again leading the nation in per capita incarceration, a prospect viewed with dismay.

This invitation from the Louisiana's District Attorneys, and their willingness to engage with the substance of my talk, may signal a greater

61 Reilly \& Nichols, supra note 40.

62 The reporter promised to look into it. As of October 6, 2020, the USA Today article still says that the office has "no list." 
open-mindedness on the part of "non-progressive" prosecutors to reform than current academic discourse suggests. If so, scholars could be missing an opportunity by focusing only on "progressive prosecutors" and (perhaps) neglecting prosecutors who would not adopt that label but are nonetheless open to reform. 